\section{B A Institute of \\ yk Business Administration \\ 六下 \\ Karachi \\ Leadership and Ideas for Tomorrow}

Business Review

Volume 16 Issue 2 July-December 2021

2022

\title{
Internal corporate governance and bank risk taking behavior: evidence from developed and emerging economies
}

Ghulam Subhani

Iqra University

Shumaila Zeb

SZABIST

Follow this and additional works at: https://ir.iba.edu.pk/businessreview

Part of the Corporate Finance Commons

\section{(c) (1)}

This work is licensed under a Creative Commons Attribution 4.0 International License.

\section{Recommended Citation}

Subhani, G., \& Zeb, S. (2022). Internal corporate governance and bank risk taking behavior: evidence from developed and emerging economies. Business Review, 16(2), 21-43. Retrieved from https://doi.org/ $10.54784 / 1990-6587.1405$

This article is brought to you by iRepository for open access under the Creative Commons Attribution 4.0 License and is available at https://ir.iba.edu.pk/businessreview/vol16/iss2/2. For more information, please contact irepository@iba.edu.pk. 


\section{Internal corporate governance and bank risk taking behavior: evidence from developed and emerging economies}

\section{Cover Page Footnote}

We would like to acknowledge the motivations and inspiration given to us by our respectable Head of the Campus Mr Khusro Pervez Khan and Head of Department Dr Muhammad Asif Khan 


\title{
Internal Corporate Governance and Bank Risk Taking Behavior: Evidence from Developed and Emerging Economies
}

\author{
Ghulam Subhani · Shumaila Zeb
}

\begin{abstract}
The study aims to evaluate the impact of board structure and ownership structure on bank risk taking behavior in developed and emerging countries. To fulfill this objective, the study used annual data of 100 large commercial banks for the period 2006-2017 from twelve countries. Zscore is used as the main proxy of bank risk taking behavior. Internal corporate governance is measured by board size, board independence, CEO power, gender diversity, state ownership and foreign ownership. The study controls the issues of endogeneity by applying a two-step generalized method of moments (GMM) econometric approach. The main findings of the study indicate that banks having a greater board size, a higher portion of independent non-executive directors, and a powerful CEO with chair role duality result in reducing the risk of bankruptcy that helps in achieving greater levels of financial stability in the banking sector. However, banks with increased female directors, higher portion of foreign and state ownership escalates the probability of insolvency risk.
\end{abstract}

Keywords Board structure, Ownership structure, Risk, GMM, Endogeneity

\section{Introduction}

Since the start of the 21st century, the accounting scandals of Adelphia, Enron, and WorldCom highlighted the issues of ethics and corporate governance (CG). These scandals caught the attention of researchers and policymakers in the field of CG (Darrat et al 2016). Moving further, the world has witnessed two serious financial crises i.e. Global financial crisis (GFC) 2007-2008 and the European sovereign debt crisis (ESDS) 2010-2011 specifically in financial institutions.

Ghulam Subhani

Iqra University, Islamabad

E-mail: ghulamsubhani544@gmail.com

Shumaila Zeb

Shaheed Zulfiqar Ali Bhutto Institute of Science and Technology (Szabist), Islamabad (C)Subhani, G., and Zeb, S. 2022 
Since the mid-1990s, most of the financial crises triggered in emerging markets have resulted in the financial turmoil of other economies around the world ${ }^{1}$. However, for the first time, the worlds most powerful and largest economy i.e. the USA was the source of global financial turmoil (Ballester et al 2019). These crises urged various governments around the world to intervene and stabilize the whole financial system (Bouzgarrou et al 2018). After GFC, it was expected that banks safeguard themselves for such future financial turbulence. However, many banks performed poorly again in ESDS of 2010-2011 (Hoque et al 2015). The most severe effects of both GFC and ESDS remained largely in the financial sector of developed countries (Mollah and Liljeblom 2016). However, CG issues are more prominent in emerging countries as they are made of weak institutions (Adegbite 2015).

In addition to the above, there is consensus in the literature that weak CG mechanisms and imprudent risk taking policies by bank executives are the main causes of both GFC and ESDS (Hoque et al 2015; Vallascas et al 2017). Therefore, risk management becomes the primary agenda for policymakers since the financial stability of banks is interlinked with the stability of the entire economy (Lassoued et al 2016). Consequently, regulators are continuously trying to improve the quality of risk management mechanisms specifically in the banking sector. Likewise, CG remains pivotal for predicting bankruptcy. However, the relationship between CG and a banks insolvency risk is not completely addressed in the literature (Darrat et al 2016). Angeloni ${ }^{2}$ makes an interesting claim by arguing that governance is the first line of defense of a banks soundness, whereas capital is the last one. Even when CG is not directly linked to any aspect of a banks balance sheet, it may play a similar role to capital . Resultantly, most corporate governance codes focus on internal CG aspects in managing firms risk (Akbar et al 2017). Hence, CG may play an imperative role in shaping banks risk taking policies.

Bearing in mind the significance of internal CG mechanism and bank risk taking after the onset of both GFC and ESDS, it is imperative to analyze the relationship between internal CG aspects, i.e. board structure and ownership structure against bank risk taking behavior in developed and emerging economies. Previous studies in this aspect mostly focused on developed markets specifically in European countries and the USA in the recent past (Akbar et al 2017; Anginer et al 2018; Apergis 2019; Berger et al 2016; Felício et al 2018). However, few studies focused on emerging markets in this context (Andrie et al 2018; Ghassan and Fachin 2016; Setiyono and Tarazi 2018).

The study used annual data of 100 large commercial banks for the period 2006-2017 from twelve countries. Zscore is used as the main proxy of the risk taking behavior of banks. Internal CG is measured by board size, board independence, CEO power, gender diversity, state ownership and foreign ownership.

\footnotetext{
1 For instance, the Mexican currency crisis of (1994-1995) disrupts the Mexican market and then it spreads to worldwide markets. Furthermore, after one year, the Asian financial crisis of (1997-1998) not only resulted in the default of Russia but also has a devastating effect on Asian economies. Likewise, the phenomenon is observed in subsequent crises of Brazil 1999, Turkey 2001, and Argentina 2002 (Ballester et al 2019)

2 Ignazio Angeloni is the member of the supervisory board of the European Central Bank.
} 
The main findings of the study indicate that banks having a greater board size, a higher portion of independent non-executive directors, and a powerful CEO with chair role duality reduces the risk of bankruptcy that helps in achieving greater levels of financial stability in the banking sector. However, for banks with increased female directors, the higher portion of foreign and state ownership escalates the probability of insolvency risk. The structure of the paper is as follows: The first part of the study is the introduction and relevant literature is described in section two. Section three elaborates the data description and methodology. Results and analysis are given in section four. The last section includes the conclusion, recommendations, and policy implications.

\section{Literature review}

\subsection{Board size (BS) and risk taking behavior of banks}

Leadership structure, composition of the board, and the size of board members are vital features affecting the efficacy of the entire board (Jensen 1993). According to the strands of agency theory, small boards can easily be handled by the CEO because of social cohesion. It also takes less time and effort on part of the CEO to take any action. On the contrary, a large board would require more effort and time to decide and take approval on a key decision (Muth and Donaldson 1998). Therefore, firms with large boards curtail CEOs power in strategic decision making process. However, stewardship theory states that a small board size can easily reach a consensus related to any important matter because a smaller group of people is more socially cohesive. In contrast, firms with large boards may face communication problems. In addition, large boards may result in increased group conflicts because every individual might present his perspective while deciding any matter of interest (O'Reilly III et al 1989). Hence, a larger board might find it difficult to agree especially when firms require to make complex and ambiguous decisions (Muth and Donaldson 1998).

The results are inconclusive in past literature; for instance, the findings of (Eisenberg et al 1998) imply that firms with large BS are made of outside directors who are more concerned about their reputation in the case of insolvency instead of being concerned about the private benefits associated with portable projects. In the case of the US, Pathan (2009) confirmed that banks with small boards pursue the interest of management that results in increased risk taking behavior by bank executives. Similarly, Wang (2012) revealed that firms tend to invest more in risky projects when they have small boards as compared to firms that possess larger boards. In addition, BS is inversely associated with credit risk levels of the UK banking sector (Lu and Boateng 2018). The results demonstrated that large boards help in decreasing bankruptcy risk. Likewise, in the case of China, the negative association between BS and credit risk is also confirmed by the Haider and Fang (2016) findings. On the contrary, in the case of Thailand, banks with smaller BS are more useful in evaluating and monitoring bank managers, whereas, banks with larger BS are more exposed to 
agency-related problems Pathan et al (2007). Interestingly, Akbar et al (2017) revealed that risk attached to financial firms of the UK is not statistically significant in relation to the size of their boards. Hence, based on previous literature and following the theoretical arguments of agency theory, we, therefore, make our first hypothesis:

$H_{1}$ : $B S$ and bank risk taking behavior are inversely related to each other in developed and emerging economies

\subsection{Board independence (BI) and risk taking behavior of banks}

The behavior of managers remains opportunistic as discussed in agency theory. They want to attain perks and privileges at the expense of shareholders money. This opportunistic behavior can only be eliminated when CEO does not possess dual role because not only does that compromise the credibility of the entire board, but also marginalizes shareholders interest. Moreover, managers contribute to agency loss when CEO holds the dual role (Donaldson and Davis 1991).

The theoretical debate about board independence revolves around the role of inside and outside directors. According to stewardship theory, inside directors who spend a large amount of time within an organization possess more technical expertise and higher information about the operations of a firm. Hence, these notable qualities make them better suited for the job of protecting shareholders' interest as compared to outside directors (Donaldson and Davis 1991. On the other hand, under the employment and reputation hypothesis of agency theory, independent (outside) directors are better at monitoring management as they are concerned about their professional image in the labor market. Therefore, they would ratify less risky investments to avoid huge losses (Jensen and Meckling 1976; Fama 1980). Similarly, outside directors are considered to be a resource for the company because they possess excessive managerial experience, skills, knowledge, qualification, and tenure as compared to inside directors. As a result, they can add value to the firm and give valuable suggestions in strategic decisions of a firm (Rashid 2015).

Recent evidence supporting the claims of agency and resource dependency theory is presented by Akbar et al (2017). Their results largely imply that as firms increase board independence, it will reduce the probability of bankruptcy. In the case of the US, Pathan et al (2007) also finds identical results as board independence and risk maintained an inverse association among different measures of risk. Furthermore, it is noted that board independence not only reduces the risk of bankruptcy, but it also helps large banks to attain better performance in the aftermath of GFC (Vallascas et al 2017). In addition, firms experience better performance when they hire more independent non-executive directors on their respective boards (Pathan et al 2007). Based on the above discussion and following the theoretical arguments of agency theory we, make our second hypothesis: 
$\mathrm{H}_{2}$ : BI and bank risk taking behavior are inversely related to each other in developed and emerging economies

\subsection{CEO power (CEOP) and risk taking behavior of banks}

The behavior of managers remains opportunistic as discussed in agency theory. They want to attain perks and privileges at the expense of shareholders money. This opportunistic behavior can only be eliminated when CEO does not possess dual role because not only does that compromise the credibility of the entire board, but also marginalizes shareholders interest. Moreover, in such a situation, managers contribute to agency loss (Donaldson and Davis 1991). On the contrary, the advocates of stewardship theory believe that managers do not pursue individualistic behavior. Instead, they want self-recognition from their bosses and peers, and carry out challenging task while exercising authority and responsibility (Donaldson and Davis 1991).

According to stewardship theory, the presence of an effective structural environment in an organization determines managerial performance. Specifically, when the role the of CEO is unchallenged and unambiguous in an organization, the common notion is that such an organization structure enables higher management to achieve superior performance. By conforming to this role, the lower level management is clear as to whom they are questionable in any matter in an organization. Moreover, by pursuing such an organizational structure, a firm can avail benefits of strong unity, control, and command (Donaldson and Davis 1991).

Although the term CEO Power is defined differently in literature, previous studies such as Fracassi and Tate (2012) revealed that when CEO has the ultimate power, it helps the CEO to develop closer ties with the board of directors that lowers bank profit margins. Furthermore, (Baklouti et al 2016) examined the financial distress of 147 European banks. The findings demonstrated that banks in which the CEO does not hold the dual role have better supervision capacity and more powerful boards at their disposal. Likewise, it is revealed that the likelihood of bankruptcy becomes higher for firms where the CEO performs the dual role (Darrat et al 2016). Nevertheless, under the employment and reputation hypothesis, managers are risk aversea finding supported by previous studies(Berger et al 2016; Pathan 2009). We follow the theoretical arguments of agency theory and make our third hypothesis:

$H_{3}$ : CEO Power and bank risk taking behavior are positively related to each other in developed and emerging economies

\subsection{Gender diversity (GD) and risk taking behavior of banks}

The theoretical aspects of board GD are linked to ethical theory. A major part of ethical theory is derived from gender social theory. It argues that men and women used to think differently when making a decision. Men are mostly goaloriented and aggressive while women have a more nurturing attitude (Eagly and 
Wood 1999). Hence, ethical issues are evaluated differently by men and women (Galbraith and Stephenson 1993). A study conducted by Peterson et al (1991) regarding business ethics issues revealed that females tend to be more ethical as compared to male students. In terms of accounting and finance literature, it is noted that unethical behavior may bring potential risks for companies. Therefore, risk management and ethical behavior cannot be separated from one another (Drennan 2004). Moreover, firms tend to use ethical behavior as a risk instrument, thereby adopting legal and ethical governance mechanism to reduce their risk appetite (Arjoon 2005).

Over the years, women made great advances in every field of life. Therefore, we witness an increase of women in management roles of firms around the world (Hillman et al 2007; Melero 2011). A high record of female CEOs i.e. 21 is present among Fortune 500 companies. However, despite this increasing trend, the number of women in management roles are considerably lower as compared to men. Thus, all these discussions make gender a notable topic among researchers and policymakers ${ }^{3}$ (Hillman et al 2007). In line with arguments of ethical theory, Farag and Mallin (2017) revealed that when females are present on bank boards, they are less exposed to a financial crisis. In addition, increased GD does help banks to maximize their financial performance, as they provide firms with unique resources. Similarly, De Cabo et al (2012) in case European banks found that financial firms take less risk as the portion of female directors are increased on their respective boards.

$H_{4}$ : GD and bank risk taking behavior are inversely related to each other in developed and emerging economies

\subsection{Foreign ownership (FO) and risk taking behavior of banks}

Berger et al (2000) explained the theoretical aspects of FO in two opposing hypotheses i.e. home field (HF) and global advantage (GA). HF hypothesis claims that foreign-owned banks are usually less effective and efficient. This is because they use to operate and monitor their respective institutes from distance and may face barriers in language, culture, and other market related supervisory structures in host countries. However, the GA hypothesis posits that banks with high FO possess greater resources, knowledge, expertise, and skills that enable them to better diversify their potential risk and generate higher returns.

In line with the GA hypothesis, Lassoued et al (2016) examined 171 commercial banks in the MENA region and finds an inverse association between FO and insolvency risk. The result can be attributed towards better monitoring and evaluation of overall risk related activities by foreign entities. Similarly, after analyzing a large sample of 322 banks from European Union, Lapteacru (2019) finds that banks with increased FO are successful in taking the global advantage of better technical expertise, excellent management skills, the use

3 The EU commission, (2012) has agreed to the proposal presented by European parliament that recommends to increase the gender quota to 40 percent in large scale enterprises as their non-executive directors till January 1st, 2020 (Szydło 2015). 
of latest technologies, and portfolio diversification of their assets in the host country. Hence, they are better capable to limit their excessive risk taking behavior. In addition, it is noted that foreign owned firms use to take less risk as they are more prudent in their risk evaluation matters (Vo 2016). Nevertheless, few studies that support the notion of HF hypothesis and finds that foreign owned banks have higher chances of bankruptcy as compared to domestic banks(Boubakri et al 2013; Caporale et al 2017). Based on above discussion and following the theoretical arguments of the GA hypothesis we, therefore, make our fifth hypothesis:

$H_{5}: F O$ and bank risk taking behavior are inversely related to each other in developed and emerging economies

\subsection{State ownership (SO) and risk raking behavior of banks}

Most countries are comprised of two-tier banking ownership structures i.e. private or public ${ }^{4}$ (Zhu and Yang 2016). A general assumption is that banks with high SO are usually inefficient. Two different theoretical aspects may explain the intervention of states in financial markets. The first one is related to Kindleberger (1963) who believes that state intervention in financial markets is necessary for economic sustainability in a country. He relates this view with an optimistic or more developmental view. However, the other view is based more on achieving political objectives instead of social development objectives. The political objectives of politicians led them to control investment by firms. They may compensate their voters in the form of giving them jobs, subsidies, and other perks and privileges, so that they have a higher chance of forming a government in the next term (La Porta et al 2002).

In line with assumptions of political theories, Lapteacru (2019) examined 644 state owned banks and 1939 foreign banks in central and eastern Europe. He found that banks with increased SO are riskier as compared to their foreign counterparts. Further, the policies pursued by state-owned banks in the selected sample make those banks as worst capitalized as compared to private banks. In the case of Zhu and Yang (2016) found a positive effect of SO on a banks credit risk after using different measures of bank risk taking behavior. The results imply that banks with SO are encouraged to take on more risk as they are being backed by their respective governments. Likewise, such banks are also found to be less prudent in their lending practices as compared to foreign banks that makes them riskier (Dong et al 2014). However, despite all these discussions, few studies that are in line with assumptions of development theories reveals that $\mathrm{SO}$ decreases the probability of bankruptcy across different economies e.g. (Iannotta et al 2013; Boubakri et al 2013). Based on empirical evidence of past studies and following the arguments of political theories we, make our sixth hypothesis:

\footnotetext{
4 As a matter of fact, almost 21 percent of worlds banking industry is under state ownership (Gonzalez-Garcia and Grigoli 2013)
} 
$H_{6}$ : SO and bank risk taking behavior are positively related to each other in developed and emerging economies

\section{Research methodology}

3.1 Data description and sample selection

The primary objective of this study is to analyze the impact of internal CG aspects on bank risk taking behavior in developed and emerging economies. Data for firm-related variables are extracted from thebankerdatabase. Data for CG-related variables are extracted from the BoardEx $x^{5}$ database and Thomson ONE Banker database. Moreover, we used World Development Indicators (WDI) to collect macroeconomic data. Following Andrie et al (2018), we collect the data of 100 large banks for the period 2006-2017 from twelve ${ }^{6}$ countries. The banks are classified according to asset size in the study. It is noted that large banks are pivotal for achieving financial stability in a country (Vallascas et al 2017). To include a bank in our sample, we adopt two different criteria. First, we only select those banks that are not delisted after GFC because their data may not be available during the time of ESDS (Mollah and Liljeblom 2016). Second, we eliminated banks whose data is not available for a consecutive period of five years; otherwise, we may not apply the generalized method of moments as our main estimation method (Florackis and Ozkan 2009; Akbar et al 2017). After applying both these criteria, we end up with 1200 annual firm year observations. The quoted number of banks in selected countries is a representation of more than $60 \%$ of total banking assets ${ }^{7}$-a representation similar to (Erkens et al (2012). Despite a relatively small sample size, this sample size is similar to previous cross-country studies (De Andres and Vallelado 2008).Furthermore, the study includes 16 systemically important banks out of 29 global systemically important financial institutions mentioned by Mollah and Liljeblom (2016) in their study.

\subsection{Variable description}

We use the accounting-based measure of bank risk taking behavior in this study i.e. Zscore (ZS), a widely used indicator of default risk and risk taking (Vallascas et al 2017; Ghassan and Fachin 2016). For robustness purposes, we use non-performing loans (NPL) as a proxy for bank risk taking (Lu and Boateng

\footnotetext{
${ }^{5}$ In case of Pakistan, data for CG variables are collected by authors from annual reports. As Boardex database dont have the availability of such data related to Pakistan.

6 Developed economies include USA, Germany, France, Spain, Italy and the UK, and emerging economies are China, India, Indonesia, Malaysia, Thailand and Pakistan. According to World Bank, more than $50 \%$ of these countries for e.g. (USA, China, Germany, United Kingdom, France, India and Italy) are included in world top 10 economies at the end of year 2018. The detailed distribution of sample is provided in Appendix A1 and A2

7 At the end of year 2006, among the selected banks, USA represent 59\%, UK $76 \%$, Thailand $84 \%$, Spain 55\%, Pakistan 95\%, Malaysia 55\%, Indonesia 71\%, India 56\%, France 68\%, China $75 \%$ and Germany $26 \%$ respectively
} 
2018). The board structure variables following Apergis (2019); Setiyono and Tarazi (2018); Mollah and Liljeblom (2016); Akbar et al (2017); Adams et al (2005) are $\mathrm{BS}^{8}$, BI, CEOP, and GD. In contrast, ownership structure variables following Lapteacru (2019); Bouzgarrou et al (2018); Caporale et al (2017) and Boubakri et al (2013). Apart from these variables, we control for firm size (FS)(Konishi and Yasuda 2004). Following Uhde (2016), we also control leverage (LEV) ratio $^{9}$ because it is pivotal for banks to maintain an appropriate capital structure. In addition, gross domestic product (GDP) and inflation (INF) are also used as control variables. According to Lassoued et al (2016), development of a country does affect the performance of banks. The INF rate determines how banks behave and affect both their assets and liabilities. Lastly, by following the methodology of Pathan et al (2007), we include the crisis dummy variable for both GFC and ESDS for the years 2007-2011. For the detailed formulation of proxies, see table 1.

\subsection{Estimation method}

The data signals both cross-sectional (multiple banks) and longitudinal (multiple years) characteristics. The bank risk heterogeneity may result in biased estimation. Therefore, to remove such concerns, we need to apply a special estimation technique (Ben Jabra et al 2017). It is necessary because explanatory variables are correlated with a lag dependent variable that makes OLS estimates biased. In addition, explanatory variables are also expected to be correlated with error terms especially when such variables are endogenous that makes such results more biased (Akbar et al 2017). All these econometric problems can be fixed by the application of two-step GMM. It corrects the aforementioned bias and also eliminates the issue of fixed effects by a first-differences transformation (Arellano and Bond 1991). Therefore, in the presence of endogeneity, using twostep GMM is considered more useful as compared to OLS or fixed effects.Hence, by following the works of Wintoki et al (2012); Zhou et al (2014) and Akbar et al (2017) we employ two-step GMM econometric model.

\subsection{Estimation model}

We use the following baseline models to examine the effect of board structure and ownership structure against bank risk taking behavior in developed and developing countries.

$$
\begin{aligned}
& Z S, N P L_{i t}=\beta_{0}+\beta_{1} Z S, N P L_{i t}+\sum_{\beta_{3}}^{4}(\text { board structure })_{i t j}+\sum_{\beta_{4}}^{2} \\
& (\text { ownership structure })_{i t j}+\beta_{5}(\text { control })_{i t j}+\beta_{6}(\text { crisis })_{i t j}+\theta \chi_{i t j}+\mu_{i, j}+e_{i t j}
\end{aligned}
$$

\footnotetext{
8 Following Akbar et al (2017)we take natural log of board size

9 We have taken natural log of leverage ratio to remove the issue of outliers.
} 
Table 1: Variable Formulation

\begin{tabular}{|c|c|c|c|}
\hline Variables & Description & Related Literature & Source \\
\hline \multicolumn{4}{|c|}{$\begin{array}{l}\text { Dependant } \\
\text { Variables }\end{array}$} \\
\hline $\mathrm{ZS}$ & $\begin{array}{l}\text { Average ROA+ } \\
\text { Capital to Asset Ra- } \\
\text { tio } \\
\text { Divided by Standard } \\
\text { Deviation of ROA }\end{array}$ & Vallascas et al (2017) & $\begin{array}{l}\text { Author's calcula- } \\
\text { tion based on the } \\
\text { banker's database }\end{array}$ \\
\hline NPL & $\begin{array}{ll}\text { Gross } & \text { non- } \\
\text { performing } & \\
\text { loans/Gross } & \text { Total } \\
\text { Loans } & \end{array}$ & Lu and Boateng (2018) & thebankerdatabase \\
\hline \multicolumn{4}{|c|}{$\begin{array}{l}\text { Independent } \\
\text { Variables }\end{array}$} \\
\hline $\mathrm{BS}$ & $\begin{array}{l}\text { Natural Log of total } \\
\text { number of board } \\
\text { members }\end{array}$ & $\begin{array}{l}\text { Apergis (2019), } \\
\text { Akbar et al (2017) }\end{array}$ & BoardEx \\
\hline $\mathrm{BI}$ & $\begin{array}{l}\text { Percentage of inde- } \\
\text { pendent } \\
\text { directors on board }\end{array}$ & $\begin{array}{l}\text { Setiyono and Tarazi } \\
(2018)\end{array}$ & BoardEx \\
\hline CEOP & $\begin{array}{l}\text { CEO's chair role du- } \\
\text { ality } \\
\text { equals } 1 \text { and } 0 \text { other- } \\
\text { wise }\end{array}$ & $\begin{array}{l}\text { Adams and Ferreira } \\
(2007)\end{array}$ & BoardEx \\
\hline GD & $\begin{array}{l}\text { Percentage of female } \\
\text { directors on board }\end{array}$ & Abad et al (2017) & BoardEx \\
\hline $\mathrm{FO}$ & $\begin{array}{l}\text { Percentage of Equity } \\
\text { held by Foreign own- } \\
\text { ers }\end{array}$ & Lassoued et al (2016) & $\begin{array}{l}\text { Thompson } \\
\text { Banker }\end{array}$ \\
\hline $\mathrm{SO}$ & $\begin{array}{l}\text { Percentage of Equity } \\
\text { held by state }\end{array}$ & Lapteacru (2019) & $\begin{array}{l}\text { Thompson } \\
\text { Banker }\end{array}$ \\
\hline \multicolumn{4}{|l|}{$\begin{array}{l}\text { Control } \\
\text { Variables }\end{array}$} \\
\hline LEV & $\begin{array}{l}\text { Natural log of Total } \\
\text { Debt/Total Equity }\end{array}$ & Uhde (2016) & thebankerdatabase \\
\hline FS & $\begin{array}{l}\text { Natural log of Total } \\
\text { Assets }\end{array}$ & $\begin{array}{l}\text { Konishi and Yasuda } \\
(2004)\end{array}$ & thebankerdatabase \\
\hline GDP & $\begin{array}{l}\text { Real GDP Growth } \\
\text { Rate }\end{array}$ & Lassoued et al (2016) & $\begin{array}{l}\text { World Develop- } \\
\text { ment Indicators }\end{array}$ \\
\hline INF & Growth of CPI & Lassoued et al (2016) & $\begin{array}{l}\text { World Develop- } \\
\text { ment Indicators }\end{array}$ \\
\hline Crisis & $\begin{array}{l}\text { Crisis equals } 1 \text { if the } \\
\text { year is } \\
2007-2011 \text { and zero } \\
\text { otherwise }\end{array}$ & Pathan and Faff (2013) & thebankerdatabase \\
\hline
\end{tabular}

$$
Z S, N P L_{i t}=\alpha_{0}+\alpha_{1} Z S, N P L_{i t}+\alpha_{2}(\text { controls })_{i t j}+\theta \chi_{i t j}+\mu_{i, j}+e_{i t j}
$$

In the above equations the left hand side variables i.e. $Z S, N P L_{i t}$ are the dependent variables used in the study. The right hand side variables include BoardStructure $_{i t j}$,OwnershipStructure Ot $_{j}$, and control $_{i t j}$. In addition, $\chi_{i t j}$ represents the exogenous variable i.e. crisis dummy, $\mu_{i j}$ denotes unobserved firm 
effects and $e_{i t j}$ stands for the residuals. For more information, please see Table 1.

\title{
4 Results and discussions
}

\author{
4.1 Summary Statistics
}

Table 2: Results of Summary Statistics for Banks of Developed Countries

\begin{tabular}{llllll}
\hline Variables & Mean & Max. & Min. & $\begin{array}{l}\text { Std. } \\
\text { Dev. }\end{array}$ & Count \\
\hline BS & 12.7 & 37 & 2.00 & 4.82 & 600 \\
BI & 0.56 & 0.93 & 0.01 & 0.29 & 600 \\
CEOP & 0.54 & 1.00 & 0.00 & 0.50 & 600 \\
GD & 0.13 & 0.55 & 0.00 & 0.11 & 600 \\
FO & 0.02 & 0.25 & 0.00 & 0.05 & 600 \\
SO & 0.02 & 0.73 & 0.00 & 0.10 & 600 \\
LEV & 6.98 & 11.1 & 6.17 & 0.45 & 600 \\
FS & 12.01 & 15.15 & 2.21 & 1.87 & 600 \\
GDP & 1.21 & 4.17 & -5.61 & 1.91 & 600 \\
INF & 1.82 & 10.13 & -0.5 & 1.23 & 600 \\
ZS & 13.96 & 45.57 & -0.77 & 7.81 & 600 \\
NPL & 3.38 & 22.84 & 0.11 & 3.19 & 600 \\
\hline
\end{tabular}

Table 2 exhibits the summary statistics for banks in developed countries. The average BS of banks in developed countries is 12.70. Maximum number of directors on board is 37 and minimum number of directors on board is 2 with a standard deviation of 4.82 which implies the dispersion among the total number of members on board for banks in developed countries. BI remains at 56 percent for banks in developed countries. Likewise, almost 54 percent of banks have a powerful CEOP. However, the mean value for GD is 0.13 . It indicates that females are working in male-dominated environments as the board of directors. The mean value for $\mathrm{FO}$ and $\mathrm{SO}$ remains identical at 0.02 . Maximum FO and $\mathrm{SO}$ is 0.25 and 0.73 respectively. The mean value of LEV ratio implies that banks are highly leveraged. The mean value of FS is 12.01. The mean value for macroeconomic variables is 1.21 and 1.82 for GDP and INF respectively. Average ZS and NPL values for banks in developed countries remain at 13.96 and 3.38 respectively.

Table 3 exhibits the summary statistics for banks in emerging countries. The mean value of bank BS in emerging countries is 10.94 almost 2 percent less than developed countries i.e. 12.70. According to Jensen (1993), the ideal board size comprises of 7 members. Maximum number of directors on board is 25 and minimum number of directors on board is 4 with a standard deviation of 3.51. In comparison to 56 percent BI in developed countries, the banks in emerging countries have only 39 independent boards. However, the mean value of $\mathrm{CEOP}$ is 0.59 as compared to 0.54 in developed countries. The mean value of

Business Review: (2021) 16(2):21-43 
G.Subhani and S.Zeb

Table 3: Results of Summary Statistics for Banks of Emerging Countries

\begin{tabular}{lccccc}
\hline Variables & Mean & Maximum & Minimum & Std. Dev. & Count \\
\hline BS & 10.94 & 25 & 4 & 3.51 & $\mathbf{6 0 0}$ \\
BI & 0.39 & 0.93 & 0.00 & 0.25 & 600 \\
CEOP & 0.59 & 1.00 & 0.00 & 0.49 & 600 \\
GD & 0.09 & 0.50 & 0.00 & 0.11 & 600 \\
FO & 0.04 & 0.63 & 0.00 & 0.10 & 600 \\
SO & 0.18 & 0.99 & 0.00 & 0.29 & 600 \\
LEV & 7.01 & 9.65 & -6.33 & 0.70 & 600 \\
FS & 10.6 & 15.2 & 5.99 & 1.91 & 600 \\
GDP & 5.86 & 14.23 & -1.51 & 2.86 & 600 \\
INF & 4.66 & 53.38 & 0.27 & 5.84 & 600 \\
ZS & 21.68 & 73.26 & -2.29 & 12.48 & 600 \\
NPL & 4.66 & 53.38 & 0.27 & 5.84 & 600 \\
\hline
\end{tabular}

GD is 0.09. It implies that similar to developed countries, females in emerging countries are also working in male dominated environments as the board of directors. The mean value for $\mathrm{FO}$ and $\mathrm{SO}$ is 0.04 and 0.18 . The banks in emerging countries have higher FO and $\mathrm{SO}$ as compared to banks in developed countries. Maximum FO and SO are 0.63 and 0.99 respectively. The mean value of the LEV ratio is 10.60 , which indicates that banks are highly leveraged similar to banks in developed countries. The mean value of FS is 10.60. In addition, the mean value for macroeconomic variables is 5.86 and 4.66 for GDP and INF respectively. The average ZS and NPL for banks in developed countries are 21.68 and 4.66 respectively.

\subsection{Regression results}

Table 4 reports results of ordinary least square (OLS) fixed effects because the p-values of the Hausman test reject the random effects null hypothesis among all three models. However, it is noted that OLS results are biased and invalid because OLS econometric approach suffers from endogeneity problems (Apergis 2019. Moreover, it is worth mentioning that board structure analysis suffers from endogeneity problems and it is one of the key concerns that need to be addressed in corporate governance studies (Hermalin and Weisbach 1991). In such circumstances, the results from OLS estimated model are deemed to be biased and inconsistent. However, despite the biasness of the OLS estimated model, it is necessary to run such a model before adopting an instrumental type of methodology such as GMM to know the difference of results between these econometric models. Hence, by following Apergis (2019) this study used OLS econometric approach before implementing the GMM approach.

The findings in Table 5 demonstrated that BS is inversely associated with bank risk taking behavior. This implies that as the board grows in size, it helps the bank to reduce its overall risk appetite. The result supports the findings of Eisenberg et al (1998) who stated that large BS mostly consists of outside directors who are concerned about their public image/reputation. As a result, they ratify less risky investments. Similar results are found by (Haider and Fang 
Internal Corporate Governance and Bank Risk Taking Behavior:...

Table 4: OLS results for Overall, Developed, and Emerging Countries

\begin{tabular}{|c|c|c|c|c|c|}
\hline Variables & $\begin{array}{l}\text { Overall } \\
\text { tries }\end{array}$ & Coun- & $\begin{array}{l}\text { Developed } \\
\text { Countries }\end{array}$ & $\begin{array}{l}\text { Emerging } \\
\text { tries }\end{array}$ & Coun- \\
\hline \multirow{2}{*}{ BS } & $-0.995^{* * *}$ & & $-0.643^{* *}$ & $-2.122^{* *}$ & \\
\hline & -0.006 & & -0.025 & -0.011 & \\
\hline \multirow{2}{*}{ BI } & $-0.804^{*}$ & & -0.611 & -1.487 & \\
\hline & -0.082 & & -0.119 & -0.112 & \\
\hline \multirow{2}{*}{ CEOP } & 0.119 & & -0.018 & -0.481 & \\
\hline & -0.648 & & -0.937 & -0.347 & \\
\hline \multirow{2}{*}{ GD } & 0.712 & & $2.151^{* *}$ & -1.101 & \\
\hline & -0.521 & & -0.027 & -0.606 & \\
\hline \multirow{2}{*}{ FO } & 3.011 & & 0.833 & 3.967 & \\
\hline & -0.104 & & -0.748 & -0.115 & \\
\hline \multirow{2}{*}{$\mathrm{SO}$} & $3.714^{* * *}$ & & $4.759^{* * *}$ & 2.761 & \\
\hline & -0.003 & & -0.008 & -0.104 & \\
\hline \multirow{2}{*}{ LEV } & $-3.139 * * *$ & & $-6.522^{* * *}$ & $-3.044^{* * *}$ & \\
\hline & 0.000 & & 0.000 & 0.000 & \\
\hline \multirow{2}{*}{ FS } & -0.063 & & $-2.614 * * *$ & $1.302 * * *$ & \\
\hline & -0.751 & & 0.000 & 0.000 & \\
\hline \multirow{2}{*}{ Crisis } & $-1.722^{* * *}$ & & $-0.855^{* * *}$ & $-1.782^{* * *}$ & \\
\hline & 0.000 & & 0.000 & 0.000 & \\
\hline R-square & 0.241 & & 0.314 & 0.302 & \\
\hline No of Obs & 1200 & & 600 & 600 & \\
\hline
\end{tabular}

Table 4 presents the ordinary least squares (OLS) fixed effects results from predicting default risk proxied by Zscore. The estimates in the first column report full sample results. P-values are mentioned below their coefficient estimates, ***,**, * presents significance level at the $1 \%, 5 \%$, and $10 \%$ respectively.

2016). Based on our findings related to BS in table 5, we accept our proposed H1. The results remained identical in developed countries contexts. On the contrary, BS remained positively associated with bank risk taking in emerging countries but such association is not significant. The reason is evident in table 3 where the average board size is approximately 10.94 for emerging countries. However, the ideal board size is seven members; if it exceeds this number, there may be communication/coordination constrains that hurts the effectiveness of entire board (Jensen 1993). Identical findings are reported by (Akbar et al 2017; Muller-Kahle and Lewellyn 2011).

Furthermore, BI is also inversely associated with bank risk taking behavior in the overall sample and emerging countries. Therefore, we accept our proposed H2. The result implies that under the employment and reputation hypothesis, independent outside directors are better at reducing agency conflicts. Following resource dependency theory, outside directors have excessive managerial experience, skills, knowledge, qualification, and tenure in comparison to inside directors (Muth and Donaldson 1998). In addition, outside directors like to keep a better professional image in the labor market, thus they are reluctant to approve risky investments that helps bank to achieve higher financial stability by avoiding huge losses (Fama 1980; Jensen and Meckling 1976). Similar empirical evidence is presented by previous studies (Pathan et al 2007; Vallascas et al 2017). However, in case of developed countries, BI maintained a positive but insignificant association with bank risk taking behavior. This positive association is found in previous studies as well (Fama and Jensen 1983; Pirson and Turnbull 
G.Subhani and S.Zeb

Table 5: GMM results for overall, developed and emerging countries

\begin{tabular}{llll}
\hline Variables & $\begin{array}{l}\text { Overall } \\
\text { Countries }\end{array}$ & $\begin{array}{l}\text { Developed } \\
\text { Countries }\end{array}$ & $\begin{array}{l}\text { Emerging } \\
\text { tries }\end{array}$ \\
\hline ZS-1 & $0.772^{* * *}$ & $0.712^{* * *}$ & $0.629^{* * *}$ \\
ZS-2 & 0.000 & 0.000 & 0.000 \\
& - & - & $0.274^{* * *}$ \\
BS & $-0.341^{* *}$ & $-0.731^{* *}$ & 0.000 \\
& -0.037 & -0.014 & 0.355 \\
BI & $-0.945^{* * *}$ & 0.001 & -0.116 \\
& 0.000 & -0.996 & $-2.569^{* * *}$ \\
CEOP & $-0.229^{* *}$ & $-0.236^{* *}$ & -0.001 \\
& -0.037 & -0.013 & -0.04 \\
GD & $0.846^{*}$ & -1.125 & -0.91 \\
& -0.098 & -0.274 & $2.986^{* * *}$ \\
FO & $4.725^{* * *}$ & $-11.487^{* *}$ & 0.000 \\
& 0.000 & -0.027 & $9.666^{* * *}$ \\
SO & $2.503^{* * *}$ & 0.26 & 0.000 \\
& 0.000 & -0.933 & $1.236^{*}$ \\
LEV & $-2.774^{* * *}$ & $-1.146^{* * *}$ & -0.055 \\
& 0.000 & 0.000 & $-2.541^{* * *}$ \\
FS & $-0.186^{* * *}$ & $0.478^{* * *}$ & 0.000 \\
& -0.008 & 0.000 & $0.824^{* * *}$ \\
Crisis & $-0.588^{* * *}$ & $-0.241^{* *}$ & 0.000 \\
AR2 & 0.000 & -0.014 & -0.031 \\
Hansen/Sargan & 0.556 & 0.748 & -0.837 \\
No of Observa- & 1100 & 0.989 & 0.136 \\
tions & & 550 & 0.996 \\
\hline
\end{tabular}

Note: Table 5 reports the results of two-step Generalized Method of Moments (GMM) estimates using ZS as a proxy of bank risk taking behavior for banks. The p-values of AR-2 correlation show that there is no issue of serial correlation in all models. According to Hansen test of over identification, all instruments are valid. P-values are mentioned in brackets below the coefficient estimates. $* * *, * *, *$ presents significance level at $1 \%, 5 \%$, and $10 \%$ respectively. In terms of the endogeneity test, the p-values of Hausman test reject the random effects null hypothesis among all three models in favor of GMM models .

2011; Sá et al 2017). The result implies that independent non-executive directors lack relevant information in comparison to inside directors, making them less effective in resolving agency conflicts and monitoring management.

The result of CEO chair role duality is negatively linked to bank risk taking behavior in all three models. It leads us to reject our proposed H3. The result implies that managers are concerned about their public image in the labor market and therefore, disapprove risky investments. Moreover, high risk taking policies pursued by bank executives might lead the bank towards default risk that could deteriorate CEO's reputation. In this way, a powerful CEO who possesses chair role duality helps bank to decrease their overall risk appetite. The results are in line with other studies(Berger et al 2016; Pathan 2009). In addition, the results of GD remained positively linked to bank risk taking in overall and emerging countries contexts. Based on such empirical evidence we reject our proposed H4. The findings suggest that increasing female portion as the board of directors results in instability of financial institutes. These results are inconsistent with the previous study such as De Andres and Vallelado (2008) but are similar 
Berger et al (2014) as they claim that increasing the number of women in the board of directors does not decrease the risk taking behavior of the German banking sector. Likewise, Adams and Funk (2012)also find that Swedish female supervisors are not more risk-averse than their male counterparts when they work in male-dominated environments. This is evident as reported in Tables 2 and 3, which show that only 11 percent of females are working as the board of directors in the selected sample. However, this association remains negative but insignificant in the case of developed countries which is similar to the findings of Sila et al (2016).

In terms of ownership structure, FO is positively linked to banks risk taking in overall and emerging countries contexts. Based on this result, we reject our proposed H5. These findings imply that banks with higher levels of FO are more susceptible to insolvency risk that may destabilize the financial sector. This empirical evidence supports the notion of the HF hypothesis (Berger et al 2000), whereby foreign entities are at disadvantage because of lower profit margins and the high cost of providing similar services in comparison to state-owned enterprises. Moreover, the barriers of culture, language, and supervisory structures make it difficult for foreign entities to outperform domestic banks. Similar results are reported by studies (Boubakri et al 2013; Caporale et al 2017; Lee and Hsieh 2014). On the contrary, FO is inversely associated with banks probability of default in developed countries. This result is in line with Lapteacru (2019). He found that foreign-owned entities have better risk management skills, resources, and policies that enable them to outperform state-owned enterprises. This inverse association supports the viewpoints of the GA hypothesis Berger et al (2000). The results also indicate that SO is positively linked to the risk taking behavior of banksin all three models. However, this association is not significant for developed countries. Based on empirical evidence reported in table 5 we accept our proposed H6. This result is similar to previous studies (Dong et al 2014; Lapteacru 2019; Zhu and Yang 2016). The results imply that state-owned bank representatives used to engage in risky investments as they are backed by the government. This makes them exposed to the risk of insolvency that may hurt the stability of the whole financial sector. In terms of control variables, LEV remains inversely associated with the risk taking behavior of banks in all three models. It implies that when banks tend to finance more through debt, it results in reducing the risk taking behavior of banks. This result contradicts the findings of Campbell and Mínguez-Vera (2008). They found that the probability of bankruptcy increased when firms take on excessive debt. However, according to Jensen (1993), higher debt may be used as an instrument to eliminate agency costs when managers tend to waste-free cash flows. In this way, firms can align the interest of principals and agents that ultimately reduce their chance of bankruptcy.

In addition, the results of FS maintained an inverse association with bank risk taking in the overall sample. The result suggests that as banks grow in size, they are more capable of diversifying their investment activities which enables them to achieve higher levels of stability(Anginer et al 2018). This is in line with the findings of Bebczuk and Galindo (2008). However, this association remained positive in subsamples of developed and emerging countries, imply-

Business Review: (2021) 16(2):21-43 
ing that if large firms know they are too big to fail, they may pursue riskier strategies, as large banks are expected to benefit from government bailouts and insurance schemes in comparison to small banks (Anginer et al 2018. Lastly, findings of crisis dummy revealed that large banks-due to their better diversification strategies-are not prone to insolvency risk during both GFC and ESDC.

Table 6: Robustness Test using Alternative Measure of Bank Risk Taking Behavior

\begin{tabular}{|c|c|c|c|}
\hline Variables & $\begin{array}{l}\text { Overall } \\
\text { Countries }\end{array}$ & $\begin{array}{l}\text { Developed } \\
\text { Countries }\end{array}$ & $\begin{array}{l}\text { Emerging } \\
\text { Countries }\end{array}$ \\
\hline & $0.814^{* * *}$ & $0.923^{* * *}$ & $0.781^{* * *}$ \\
\hline NPL-1 & 0.000 & 0.000 & 0.000 \\
\hline NPL-2 & - & $\begin{array}{l}-0.204^{* * *} \\
0.000\end{array}$ & - \\
\hline BS & $\begin{array}{l}-0.184^{* *} \\
-0.011\end{array}$ & $\begin{array}{l}0.474^{* * *} \\
0.000\end{array}$ & $\begin{array}{l}-0.644^{* * *} \\
0.000\end{array}$ \\
\hline BI & $\begin{array}{l}1.634^{* * * *} \\
0.000\end{array}$ & $\begin{array}{l}1.251^{* * *} \\
0.000\end{array}$ & $\begin{array}{l}3.301^{* * *} \\
0.000\end{array}$ \\
\hline CEOP & $\begin{array}{l}0.410^{* * *} \\
0.000\end{array}$ & $\begin{array}{l}0.981^{* * *} \\
0.000\end{array}$ & $\begin{array}{l}-0.538^{* * *} \\
0.000\end{array}$ \\
\hline GD & $\begin{array}{l}-0.627^{* * * *} \\
-0.002\end{array}$ & $\begin{array}{l}-1.661^{* * *} \\
0.000\end{array}$ & $\begin{array}{l}1.418^{* * *} \\
-0.003\end{array}$ \\
\hline FO & $\begin{array}{l}7.715^{* * *} \\
0.000\end{array}$ & $\begin{array}{l}7.783^{* * * *} \\
0.000\end{array}$ & $\begin{array}{l}6.094^{* * *} \\
0.000\end{array}$ \\
\hline SO & $\begin{array}{l}0.582^{* * *} \\
0.000\end{array}$ & $\begin{array}{l}-9.882^{* * *} \\
0.000\end{array}$ & $\begin{array}{l}1.754^{* * *} \\
0.000\end{array}$ \\
\hline LEV & $\begin{array}{l}0.730^{* * * *} \\
0.000\end{array}$ & $\begin{array}{l}1.371^{* * *} \\
0.000\end{array}$ & $\begin{array}{l}0.543^{* * *} \\
0.000\end{array}$ \\
\hline FS & $\begin{array}{l}0.070^{* *} \\
-0.079\end{array}$ & $\begin{array}{l}0.572^{* * *} \\
0.000\end{array}$ & $\begin{array}{l}-0.793^{* * *} \\
0.000\end{array}$ \\
\hline Crisis & $\begin{array}{l}-0.094^{* * *} \\
0.000\end{array}$ & $\begin{array}{l}0.145^{* * *} \\
0.000\end{array}$ & $\begin{array}{l}-0.869^{* * *} \\
0.000\end{array}$ \\
\hline $\begin{array}{l}\text { AR2 } \\
\text { Hansen/Sargan }\end{array}$ & $\begin{array}{l}0.334 \\
0.195\end{array}$ & $\begin{array}{l}0.184 \\
0.951\end{array}$ & $\begin{array}{l}0.301 \\
0.984\end{array}$ \\
\hline $\begin{array}{l}\text { No of Observa- } \\
\text { tions }\end{array}$ & 1100 & 500 & 550 \\
\hline
\end{tabular}

Table 6 reports the results of two-step GMM estimates using NPL as a proxy of default risk for banks. The pvalues of the AR-2 correlation show that there is no issue of serial correlation in all models. According to Hansen's test of over-identification, all instruments are valid. P-values are mentioned in brackets below the coefficient estimates. ${ }^{* * *}, * *, *$ presents significance level at the $1 \%, 5 \%$, and $10 \%$ respectively.

Table 6 reports the results of internal CG and bank risk taking behavior using alternate proxy i.e. NPL. The results largely remain identical to our findings presented in table 5. However, the results of LEV in all three models using NPL as a measure of bank risk taking is opposite to the results in table 5. Banks often use high debt to escalate their business growth and it is also used as an instrument to eliminate agency cost when managers tend to waste-free cash flows. However, excessive debt beyond a threshold may increase the chances of bankruptcy. Excessive debt taking might signal investors that the firm is not able to generate positive cash flows on its own, which may hurt the reputation 
of that respective firm. This result is likewise to the findings of Campbell and Mínguez-Vera (2008). They found that the probability of bankruptcy increased when firms take on excessive debt. The difference in results are mainly attributed to the economic conditions of different countries and formulations of bank risk taking behavior proxies as mentioned in table 1 .

Table 7: Macroeconomic Variables and Bank Risk Taking Behavior

\begin{tabular}{lllllll}
\hline \multicolumn{2}{c}{ ZS Results } & \multicolumn{5}{c}{ NPL Results } \\
\hline \multicolumn{2}{r}{$\begin{array}{l}\text { VariablesOverall } \\
\text { Countries }\end{array}$} & $\begin{array}{l}\text { DevelopedEmerging Overall } \\
\text { Countries Countries Countries }\end{array}$ & $\begin{array}{l}\text { Developed } \\
\text { Countries }\end{array}$ & $\begin{array}{l}\text { Emerging } \\
\text { Countries }\end{array}$ \\
\hline GDP & $-0.189^{* * *}$ & -0.016 & 0.079 & $-0.141^{* * *}$ & $-0.756^{* * *}$ & $-0.124^{* * *}$ \\
& 0.000 & -0.907 & -0.003 & 0.000 & 0.000 & 0.000 \\
INF & $0.077^{* * *}$ & -0.05 & 0.051 & $0.048^{* * *}$ & $-0.086^{* * *}$ & $0.116^{* * *}$ \\
AR2 & 0.000 & -0.837 & -0.13 & 0.000 & 0.000 & 0.000 \\
Hansen/ & 0.216 & 0.273 & 0.457 & 0.306 & 0.815 & 0.323 \\
Sargan & 0.07 & 0.994 & 0.989 & 0.05 & 0.961 & 0.942 \\
No of & 1100 & 550 & 500 & 1100 & 550 & 550 \\
Obs & & & & & \\
\hline
\end{tabular}

Note: Table 7 reports the results of two-step (GMM) estimates using ZS and NPL as a proxy of bank risk taking behavior. The p-values of the AR-2 correlation show that there is no issue of serial correlation in all models. According to Hansen's over-identification, all instruments are valid. P-values are mentioned in brackets below the coefficient estimates. $* * *, * *, *$ presents significance level at the $1 \%, 5 \%$, and $10 \%$ respectively.

The results in Table 7 indicate that an increased growth rate in terms of higher GDP results in decreasing overall risk taking behavior that helps in achieving higher financial stability. The result implies that during times of economic growth, banks are in a better position to pay off their debts by increasing the lending capacity, which helps them reduce their respective risk appetite. This inverse relationship between GDP and bank risk taking behavior is likewise to the findings of (Yurdakul 2014). In terms of inflation, we find contrasting results, for overall and emerging countries we find a positive association between inflation and bank risk taking using ZS and NPL as measures of bank risk taking behavior. It implies that during an inflationary period, it is difficult for banks to recover their bad debts because purchasing power parity decreases that may hurt the stability of financial institutions. On the contrary, the results of developed countries revealed otherwise for both measures of bank risk taking behavior. The inverse association between inflation and bank risk taking behavior is similar to the findings presented by (Anginer et al 2018).

\section{Conclusion}

The main objective of this study is to evaluate the impact of board structure and ownership structure on bank risk taking behavior in developed and emerging countries. To fulfill this objective, the study used annual data of 100 large

Business Review: (2021) 16(2):21-43 
commercial banks for the period 2006-2017 from twelve countries. Zscore is used as the main proxy of bank risk taking behavior. After controlling the problem of endogeneity by using two-step (GMM) econometric approach, we found that banks with a greater board size, higher portion of independent nonexecutive directors, and a powerful CEO with chair role duality decreases the risk of bankruptcy, which, in turn helps in achieving greater levels of financial stability in the banking sector. However, banks with an increased number of females on board, higher foreign and state ownership escalate the risk taking behavior of banks that may increase the chances of insolvency.

The findings of this study have several important policy implications. Based on the results of study, we recommend that policymakers should encourage and facilitate the inclusion of independent non-executive directors/outside directors on bank boards as under reputational and employment hypothesis, they restrict banks to take excessive risks. This may help in balancing the interest of shareholders and management on one hand while on the other hand, it may result in increased stability of the banking institutions. Furthermore, we call on regulators to reconsider the recent bill passed by the European parliament to increase the board gender quota to at least 40 percent in large organizations as our results suggest that women are not risk-averse. In addition, we recommend policymakers to make such policies that eliminate the barriers for foreign-owned banks in the host country. This is because foreign-owned enterprises bring foreign direct investment (FDI) and employment opportunities that may result in rapid economic growth in the host country. Lastly, we call on stakeholders to make such rules and regulations that restrict state owned banks to pursue risky investments even when they are backed by their respective governments.

Lastly, the study comes up with several limitations. First, due to the unavailability of historical data we are unable to confirm our baseline results with alternate default risk measures such as bond credit spreads, loan spreads, and bond recovery rates. Likewise, other board structure characteristics such as directors compensation, education, political connections, and key shareholdings in other companies are not covered in this study. However, these avenues are left for future research along with the inclusion of different variables that may differentiate corporate governance models and bank risk taking behavior in developed and emerging markets. Future studies may also investigate the role of corporate governance in relation to bank risk taking after the onset of GFC and ESDS.

\section{References}

Abad D, Lucas-Pérez ME, Minguez-Vera A, Yagüe J (2017) Does gender diversity on corporate boards reduce information asymmetry in equity markets? BRQ Business Research Quarterly 20(3):192-205

Adams RB, Ferreira D (2007) A theory of friendly boards. The journal of finance 62(1):217250

Adams RB, Funk P (2012) Beyond the glass ceiling: Does gender matter? Management science 58(2):219-235

Adams RB, Almeida H, Ferreira D (2005) Powerful ceos and their impact on corporate performance. The Review of Financial Studies 18(4):1403-1432 
Adegbite E (2015) Good corporate governance in nigeria: Antecedents, propositions and peculiarities. International business review 24(2):319-330

Akbar S, Kharabsheh B, Poletti-Hughes J, Shah SZA (2017) Board structure and corporate risk taking in the uk financial sector. International Review of Financial Analysis 50:101110

Andrie AM, Căpraru B, Nistor S (2018) Corporate governance and efficiency in banking: evidence from emerging economies. Applied Economics 50(34-35):3812-3832

Anginer D, Demirguc-Kunt A, Huizinga H, Ma K (2018) Corporate governance of banks and financial stability. Journal of Financial Economics 130(2):327-346

Apergis N (2019) Financial experts on the board: does it matter for the profitability and risk of the uk banking industry? Journal of Financial Research 42(2):243-270

Arellano M, Bond S (1991) Some tests of specification for panel data: Monte carlo evidence and an application to employment equations. The review of economic studies 58(2):277-297

Arjoon S (2005) Corporate governance: An ethical perspective. Journal of business ethics 61(4):343-352

Baklouti N, Gautier F, Affes H (2016) Corporate governance and financial distress of european commercial banks. Journal of Business Studies Quarterly 7(3):75

Ballester L, Díaz-Mendoza AC, González-Urteaga A (2019) A systematic review of sovereign connectedness on emerging economies. International Review of Financial Analysis 62:157163

Bebczuk R, Galindo A (2008) Financial crisis and sectoral diversification of argentine banks, 1999-2004. Applied Financial Economics 18(3):199-211

Ben Jabra W, Mighri Z, Mansouri F (2017) Determinants of european bank risk during financial crisis. Cogent economics \& finance 5(1):1298,420

Berger AN, DeYoung R, Genay H, Udell GF (2000) Globalization of financial institutions: Evidence from cross-border banking performance. Brookings-Wharton papers on financial services 2000(1):23-120

Berger AN, Kick T, Schaeck K (2014) Executive board composition and bank risk taking. Journal of Corporate Finance 28:48-65

Berger AN, Imbierowicz B, Rauch C (2016) The roles of corporate governance in bank failures during the recent financial crisis. Journal of Money, Credit and Banking 48(4):729-770

Boubakri N, Cosset JC, Saffar W (2013) The role of state and foreign owners in corporate risk-taking: Evidence from privatization. Journal of Financial Economics 108(3):641-658

Bouzgarrou H, Jouida S, Louhichi W (2018) Bank profitability during and before the financial crisis: Domestic versus foreign banks. Research in International Business and Finance 44:26-39

Campbell K, Mínguez-Vera A (2008) Gender diversity in the boardroom and firm financial performance. Journal of business ethics 83(3):435-451

Caporale GM, Lodh S, Nandy M (2017) The performance of banks in the mena region during the global financial crisis. Research in International Business and Finance 42:583-590

Darrat AF, Gray S, Park JC, Wu Y (2016) Corporate governance and bankruptcy risk. Journal of Accounting, Auditing \& Finance 31(2):163-202

De Andres P, Vallelado E (2008) Corporate governance in banking: The role of the board of directors. Journal of banking \& finance 32(12):2570-2580

De Cabo RM, Gimeno R, Nieto MJ (2012) Gender diversity on european banks boards of directors. Journal of Business Ethics 109(2):145-162

Donaldson L, Davis JH (1991) Stewardship theory or agency theory: Ceo governance and shareholder returns. Australian Journal of management 16(1):49-64

Dong Y, Meng C, Firth M, Hou W (2014) Ownership structure and risk-taking: Comparative evidence from private and state-controlled banks in china. International Review of Financial Analysis 36:120-130

Drennan LT (2004) Ethics, governance and risk management: lessons from mirror group newspapers and barings bank. Journal of business ethics 52(3):257-266

Eagly AH, Wood W (1999) The origins of sex differences in human behavior: Evolved dispositions versus social roles. American psychologist 54(6):408

Eisenberg T, Sundgren S, Wells MT (1998) Larger board size and decreasing firm value in small firms. Journal of financial economics 48(1):35-54

Erkens DH, Hung M, Matos P (2012) Corporate governance in the 2007-2008 financial crisis: Evidence from financial institutions worldwide. Journal of corporate finance 18(2):389-411

Business Review: (2021) 16(2):21-43 
Fama EF (1980) Agency problems and the theory of the firm. Journal of political economy 88(2):288-307

Fama EF, Jensen MC (1983) Separation of ownership and control. The journal of law and Economics 26(2):301-325

Farag H, Mallin C (2017) Board diversity and financial fragility: Evidence from european banks. International Review of Financial Analysis 49:98-112

Felício JA, Rodrigues R, Grove H, Greiner A (2018) The influence of corporate governance on bank risk during a financial crisis. Economic research-Ekonomska istraživanja 31(1):10781090

Florackis C, Ozkan A (2009) The impact of managerial entrenchment on agency costs: An empirical investigation using uk panel data. European Financial Management 15(3):497528

Fracassi C, Tate G (2012) External networking and internal firm governance. The Journal of finance 67(1):153-194

Galbraith S, Stephenson HB (1993) Decision rules used by male and female business students in making ethical value judgments: Another look. Journal of Business Ethics 12(3):227233

Ghassan HB, Fachin S (2016) Time series analysis of financial stability of banks: Evidence from saudi arabia. Review of Financial Economics 31:3-17

Gonzalez-Garcia MJ, Grigoli F (2013) State-owned banks and fiscal discipline. International Monetary Fund

Haider J, Fang HX (2016) Board size and corporate risk: evidence from china. Journal of Asia-Pacific Business 17(3):229-248

Hermalin BE, Weisbach MS (1991) The effects of board composition and direct incentives on firm performance. Financial management pp 101-112

Hillman AJ, Shropshire C, Cannella Jr AA (2007) Organizational predictors of women on corporate boards. Academy of Management Journal 50(4):941-952

Hoque H, Andriosopoulos D, Andriosopoulos K, Douady R (2015) Bank regulation, risk and return: Evidence from the credit and sovereign debt crises. Journal of banking \& finance 50:455-474

Iannotta G, Nocera G, Sironi A (2013) The impact of government ownership on bank risk. Journal of Financial Intermediation 22(2):152-176

Jensen MC (1993) The modern industrial revolution, exit, and the failure of internal control systems. the Journal of Finance 48(3):831-880

Jensen MC, Meckling WH (1976) Theory of the firm: Managerial behavior, agency costs and ownership structure. Journal of financial economics 3(4):305-360

Kindleberger CP (1963) Economic backwardness in historical perspective: A book of essays. by alexander gerschenkron. The Journal of Economic History 23(3):360-362

Konishi M, Yasuda Y (2004) Factors affecting bank risk taking: Evidence from japan. Journal of Banking \& Finance 28(1):215-232

La Porta R, Lopez-de Silanes F, Shleifer A (2002) Government ownership of banks. The Journal of Finance 57(1):265-301

Lapteacru I (2019) Do bank activities and funding strategies of foreign and state-owned banks have a differential effect on risk-taking in central and eastern europe? Economics of Transition and Institutional Change 27(2):541-576

Lassoued N, Sassi H, Attia MBR (2016) The impact of state and foreign ownership on banking risk: Evidence from the mena countries. Research in International Business and Finance $36: 167-178$

Lee CC, Hsieh MF (2014) Bank reforms, foreign ownership, and financial stability. Journal of International Money and Finance 40:204-224

Lu J, Boateng A (2018) Board composition, monitoring and credit risk: evidence from the uk banking industry. Review of Quantitative Finance and Accounting 51(4):1107-1128

Melero E (2011) Are workplaces with many women in management run differently? Journal of Business Research 64(4):385-393

Mollah S, Liljeblom E (2016) Governance and bank characteristics in the credit and sovereign debt crises-the impact of ceo power. Journal of financial stability 27:59-73

Muller-Kahle MI, Lewellyn KB (2011) Did board configuration matter? the case of us subprime lenders. Corporate Governance: An International Review 19(5):405-417 
Muth M, Donaldson L (1998) Stewardship theory and board structure: A contingency approach. Corporate Governance: An International Review 6(1):5-28

O'Reilly III CA, Caldwell DF, Barnett WP (1989) Work group demography, social integration, and turnover. Administrative science quarterly pp 21-37

Pathan S (2009) Strong boards, ceo power and bank risk-taking. Journal of banking \& finance 33(7):1340-1350

Pathan S, Faff R (2013) Does board structure in banks really affect their performance? Journal of Banking \& Finance 37(5):1573-1589

Pathan S, Skully M, Wickramanayake J (2007) Board size, independence and performance: An analysis of thai banks. Asia-Pacific Financial Markets 14(3):211-227

Peterson RA, Beltramini RF, Kozmetsky G (1991) Concerns of college students regarding business ethics: A replication. Journal of Business Ethics 10(10):733-738

Pirson M, Turnbull S (2011) Corporate governance, risk management, and the financial crisis: An information processing view. Corporate Governance: An International Review 19(5):459-470

Rashid A (2015) Revisiting agency theory: Evidence of board independence and agency cost from bangladesh. Journal of Business Ethics 130(1):181-198

Sá TM, Neves ED, Góis CG (2017) The influence of corporate governance on changes in risk following the global financial crisis: evidence from the portuguese stock market. Journal of Management \& Governance 21(4):841-878

Setiyono B, Tarazi A (2018) Does diversity of bank board members affect performance and risk? evidence from an emerging market. In: Corporate governance in banking and investor protection, Springer, pp 185-218

Sila V, Gonzalez A, Hagendorff J (2016) Women on board: does boardroom gender diversity affect firm risk? Journal of Corporate Finance 36:26-53

Szydło M (2015) Gender equality on the boards of eu companies: between economic efficiency, fundamental rights and democratic legitimisation of economic governance. European Law Journal 21(1):97-115

Uhde A (2016) Risk-taking incentives through excess variable compensation: Evidence from european banks. The Quarterly Review of Economics and Finance 60:12-28

Vallascas F, Mollah S, Keasey K (2017) Does the impact of board independence on large bank risks change after the global financial crisis? Journal of Corporate Finance 44:149-166

Vo XV (2016) Foreign investors and corporate risk taking behavior in an emerging market. Finance Research Letters 18:273-277

Wang CJ (2012) Board size and firm risk-taking. Review of Quantitative Finance and Accounting 38(4):519-542

Wintoki MB, Linck JS, Netter JM (2012) Endogeneity and the dynamics of internal corporate governance. Journal of financial economics 105(3):581-606

Yurdakul F (2014) Macroeconomic modelling of credit risk for banks. Procedia-Social and behavioral sciences 109:784-793

Zhou Q, Faff R, Alpert K (2014) Bias correction in the estimation of dynamic panel models in corporate finance. Journal of Corporate Finance 25:494-513

Zhu W, Yang J (2016) State ownership, cross-border acquisition, and risk-taking: Evidence from chinas banking industry. Journal of Banking \& Finance 71:133-153

\section{Appendix}

Business Review: (2021) 16(2):21-43 


\begin{tabular}{|c|c|c|}
\hline S.No & Country & Bank \\
\hline 1 & France & BNP Paribas \\
\hline 2 & France & Credit Agricole \\
\hline 3 & France & Societe Generale \\
\hline 4 & Germany & Commerzbank AG \\
\hline 5 & Germany & Deutsche Bank \\
\hline 6 & Italy & Banca Monte dei Paschi di Siena \\
\hline 7 & Italy & Banca Popolare di Milano \\
\hline 8 & Italy & Banca Popolare di Sondrio \\
\hline 9 & Italy & Cassa di Risparmio di Genova e Imperia \\
\hline 10 & Italy & Credito Valtellinese \\
\hline 11 & Italy & Mediobanca \\
\hline 12 & Italy & UNICREDIT \\
\hline 13 & Italy & Unione di Banche Italiane \\
\hline 14 & Spain & Banco Popular \\
\hline 15 & Spain & BANCO SANTANDER \\
\hline 16 & Spain & BANKINTER \\
\hline 17 & Spain & BBVA SA (Banco Bilbao Vizcaya Argentaria) \\
\hline 18 & UK & Barclays Bank \\
\hline 19 & UK & Bradford \& Bingley plc \\
\hline 20 & UK & Close Brothers Group \\
\hline 21 & UK & HSBC Holdings \\
\hline 22 & UK & Lloyds Banking Group \\
\hline 23 & UK & Royal Bank of Scotland \\
\hline 24 & UK & Standard Chartered UK \\
\hline 25 & USA & East West Bancorp, Inc. \\
\hline 26 & USA & Associated Banc-Corp \\
\hline 27 & USA & Bank of America \\
\hline 28 & USA & BB\&T Corp \\
\hline 29 & USA & Citigroup Inc. \\
\hline 30 & USA & Comerica Inc. \\
\hline 31 & USA & Cullen-Frost Bankers Inc \\
\hline 32 & USA & F.N.B. Corp. (PA) (FNB Corp.) \\
\hline 33 & USA & Fifth Third Bancorp \\
\hline 34 & USA & First Horizon National Corp. \\
\hline 35 & USA & Hancock Holding Co \\
\hline 36 & USA & Huntington Bancshares \\
\hline 37 & USA & JPMORGAN CHASE \& CO \\
\hline 38 & USA & KEYCORP INC \\
\hline 39 & USA & M\&T BANK CORP \\
\hline 40 & USA & New York Community Bancorp Inc \\
\hline 41 & USA & PNC Financial Services Group. \\
\hline 42 & USA & Regions Financial Corp. \\
\hline 43 & USA & SunTrust Banks Inc. \\
\hline 44 & USA & Synovus Financial Corp \\
\hline 45 & USA & Texas Capital Bancshares \\
\hline 46 & USA & U.S. Bancorp \\
\hline 47 & USA & UMPQUA Holdings Crop \\
\hline 48 & USA & Valley National Bancrop \\
\hline 49 & USA & Wells \& Fargo \& Co. \\
\hline 50 & USA & Zions Bancorporation \\
\hline
\end{tabular}


Internal Corporate Governance and Bank Risk Taking Behavior:...

A2 Sample Distribution from Emerging Economies

\begin{tabular}{|c|c|c|}
\hline S.No & Country & Bank \\
\hline 1 & China & Bank of China Limited \\
\hline 2 & China & Bank of Communications Co Ltd \\
\hline 3 & China & Bank of Ningbo Co. \\
\hline 4 & China & China CITIC Bank Corporation Limited \\
\hline 5 & China & China Construction Bank \\
\hline 6 & China & China Everbright Bank \\
\hline 7 & China & China Merchant's Bank Co. \\
\hline 8 & China & China MinSheng Banking Corporation \\
\hline 9 & China & Chongqing Rural Commercial Bank Co Ltd \\
\hline 10 & China & Industrial and Commercial Bank of China \\
\hline 11 & China & Ping An Bank Co Ltd \\
\hline 12 & India & Shanghaipudong Development Bank \\
\hline 13 & India & Axis Bank \\
\hline 14 & India & Bank of India \\
\hline 15 & India & Bankbaroda \\
\hline 16 & India & Canara Bank Ltd. \\
\hline 17 & India & HDFC BANK \\
\hline 18 & India & ICICI Bank \\
\hline 19 & India & IndusInd Bank \\
\hline 20 & India & State Bank of India \\
\hline 21 & Indonesia & Bank Central Asia \\
\hline 22 & Indonesia & Bank Mandiri (Persero) Tbk PT \\
\hline 23 & Indonesia & Bank Negara Indonesia (Persero) Tbk \\
\hline 24 & Indonesia & Bank Rakyat Indonesia \\
\hline 25 & Malaysia & Alliance Investment Bank \\
\hline 26 & Malaysia & AM BANK \\
\hline 27 & Malaysia & CIMB Group \\
\hline 28 & Malaysia & Hong Leong Bank Berhad \\
\hline 29 & Malaysia & Malayan Banking Berhad \\
\hline 30 & Malaysia & Public Bank \\
\hline 31 & Pakistan & Allied Bank Limited \\
\hline 32 & Pakistan & Askari LTD \\
\hline 33 & Pakistan & Bank AL Falah \\
\hline 34 & Pakistan & Bank AL Habib \\
\hline 35 & Pakistan & Bank of Punjab \\
\hline 36 & Pakistan & Faysal Bank \\
\hline 37 & Pakistan & Habib Bank Limited \\
\hline 38 & Pakistan & Habib Metropolitan Bank \\
\hline 39 & Pakistan & Muslim Commercial Bank \\
\hline 40 & Pakistan & National Bank of Pakistan \\
\hline 41 & Pakistan & Soneri Bank \\
\hline 42 & Pakistan & Standard Charter Pakistan \\
\hline 43 & Pakistan & United Bank Limited \\
\hline 44 & Thailand & Bangkok Bank Public Company Limited \\
\hline 45 & Thailand & Bank of Ayudhya Public Company Limited \\
\hline 46 & Thailand & Kasikornbank \\
\hline 47 & Thailand & Krung Thai Bank \\
\hline 48 & Thailand & The Siam Commercial Bank \\
\hline 49 & Thailand & TISCO Financial Group Public Company Limited \\
\hline 50 & Thailand & TMB Bank Public Company Limited \\
\hline
\end{tabular}

Business Review: (2021) 16(2):21-43 